Drink. Water Eng. Sci. Discuss., https://doi.org/10.5194/dwes-2018-41

Manuscript under review for journal Drink. Water Eng. Sci.

Discussion started: 20 December 2018

(c) Author(s) 2018. CC BY 4.0 License.

\title{
Optimization shallow groundwater quality by the application of photocatalysis treatment technique in El Obour city, Egypt
}

\author{
El-Montser M. Seleem ${ }^{1}$, Hossam A. El Nazer ${ }^{2}$, Salah A.M. Zeid ${ }^{1}$, Salman A. Salman ${ }^{3}$, Mahmoud A. \\ Abdel-Hafiz ${ }^{1}$
}

$5 \quad{ }^{1}$ Geology Department, Faculty of Science, Al-Azhar University, Assiut, Egypt.

${ }^{2}$ Chemical Sciences Department, National Research Centre, Dokki, Cairo, Egypt.

${ }^{3}$ Geological Sciences Department, National Research Centre, Dokki, Cairo, Egypt.

Correspondence to: Mahmoud A. Abdel-Hafiz (Elkarim_mahmoud@azhar.edu.eg)

\begin{abstract}
10 Collection of shallow groundwater and injecting it into the underline Miocene aquifer is a great environmental problem on the groundwater resources at El Obour city and environs. The present research work aims to investigate this water quality and validity of photocatalytic treatment of polluted water using nano-titania in presence of solar radiation. Twenty-eight representative samples were collected from various locations and their physical, chemical and microbial characteristics were determined. Bacteria analysis has been investigated for the presence of total bacterial count and indicator bacteria include total coliform, fecal coliform and fecal streptococci. The heavy metal analysis shows that more than $85 \%$ of the samples could be used for drinking in comparison with WHO specification for drinking water. The main pollutants in these samples are Cd and $\mathrm{Pb}$. All the studied samples contain a viable count of heterotrophic bacteria, total coliform, fecal coliform and fecal streptococci, indicating the contamination with human and animal fecal material. The high number of indicator microorganism counts observed reflected the poor quality of water. The photocatalytic technique shows high efficiency towards the removal of more than $95 \%$ and $82 \%$ of microbial pollutants and organic residuals; respectively.
\end{abstract}

\section{Introduction}

The quality of water becomes one of the most demands in recent years due to the growing pressure of population, reclamation projects and industrial development. Therefore, the need for good water quality resources is great and comes as an essential necessity (Zeid et al., 2015; Zeid et al., 2018). The most popular water pollutants are heavy metals and bacteria; although numerous heavy metals are vital in small amounts for the normal development of the biological cycles, the majority of them become dangerous in high concentrations. In recent years, human exposure has raised dramatically as a consequence an exponential increase of their utilization in several agricultural, industrial and domestic applications (Bradl, 2002; Abdel-Hafiz, 2017). 
Drink. Water Eng. Sci. Discuss., https://doi.org/10.5194/dwes-2018-41

Manuscript under review for journal Drink. Water Eng. Sci.

Discussion started: 20 December 2018

(c) Author(s) 2018. CC BY 4.0 License.

Biological contamination of water is usually caused by the presence of living organisms, such as algae, bacteria, protozoan, or viruses. Each of these can cause distinctive problems in the water. Bacteria can be caused typhoid fever, dysentery, cholera, and gastroenteritis. Bacteria that either produce or are involved in the production of a disease called pathogenic bacteria. Pathogens that contaminate drinking water originate from the contamination of water resources, even during treatment and within the distribution system (Gray, 2014). Therefore, their presence is determined by testing for the presence of an indicator organism, usually coliform bacteria (Adam Sigler and Bauder, 2011; Kamel, 2016; Ramadan, 2016). Microbial contamination of drinking water is a major contributor to water-borne diseases like diarrhea, nausea, gastroenteritis, typhoid, dysentery and other health-related problems (WHO, 1996; Shar et al., 2008), especially in children and persons with weak immune systems (PCRWR, 2005).

Chlorine is most widely used for drinking water treatment due to its low cost and disinfect water rapidly. However, disadvantages of water treatment with chlorine include, interact with any organic compounds in the water to produce disinfection by-products (DBPs) and to dissipate rapidly in distribution systems (WHO, 2000; Hrudey, 2009; Zhang et al., 2018). Approximately 600 DBPs are identified, by-products of this reaction include, for example some highly toxic compounds such as iodo and bromo compounds (Richardson et al., 2003; Plewa et al., 2004; Krasner et al., 2006; Deborde and Gunten, 2008), trihalomethanes (THMs) such as chloroform that is a cancer-causing agent and bromate are regulated due to their human health risk (NRC, 1977; Richardson, 2005; WHO, 2005; Murray et al., 2012). Furthermore, chlorine has limited efficacy against protozoan pathogens which an important cause of child diarrhea (Kotloff et al., 2013; Liu et al., 2016; Crider et al., 2018).

Photocatalysis has been extensively studied and widely applied to environmental purification both in gas and liquid phases. This could be attributed to that the photoactivated semiconductors could completely decompose (mineralize) various kinds of organic pollutants and bacteria that are refractory, toxic, and non-biodegradable, to $\mathrm{CO}_{2}$ and $\mathrm{H}_{2} \mathrm{O}$ under mild conditions (room temperature and atmospheric pressure). In contrast, application of semiconductor photocatalysis by semiconductor materials has received much attention during the last three decades as a promising solution for both energy generation and environmental problems (Fuldner et al., 2010; Fuldner et al., 2011; Gagnon et al., 2016).

Titanium dioxide, as a cheap, non-toxic, and highly efficient photocatalyst, has been extensively applied for degradation of organic pollutants, for air purification, as a deodorant, for sterilization, and as air filter (Linsebigler et al., 1995). However, because of the wide band gap of titanium dioxide, only a small UV fraction of solar light (3-5\%) can be utilized. Therefore, the most important and challenging issue is to develop efficient visible light sensitive photocatalysts by the modification of titanium dioxide. In the last years, anion doping of $\mathrm{TiO}_{2}$ films and powders with elements like nitrogen (Gole et al., 2004; Batzill et al., 2006).

Since years ago, shallow groundwater table (waterlogging or saturation of soil with groundwater) raised in some places in El Obour city. It has a dangerous effect on the infrastructure in the study area and the lower groundwater aquifer quality (Zeid et al., 2015; Elnazer et al., 2017; Zeid et al., 2018). El Obour city council tried to solve this problem by setting up plenty of wells for collecting water and injecting it into the underline Miocene aquifer. These waters are expected to be 
Drink. Water Eng. Sci. Discuss., https://doi.org/10.5194/dwes-2018-41

Manuscript under review for journal Drink. Water Eng. Sci.

Discussion started: 20 December 2018

(c) Author(s) 2018. CC BY 4.0 License.

overloaded with organic, inorganic and biological pollutants which will adversely impact the underline groundwater aquifer. As a consequent of huge quantity of water loaded with fine sediments and presence of plant roots, large number of wells blocked up leading to the increase of water again (AlShahat et al., 2014; Abou Heleika and Atwia, 2015; Seleem et al., 2015; Zeid et al., 2017; Abdel-Hafiz et al., 2018). So, the scope of the present study is to find the optimal solution for the protection of the area from waterlogging environmental impacts through, determine the water quality from the different drilled wells in El Obour city according to its content of some heavy metals and biological loads. In addition, Application of new advanced photocatalytic techniques for water treatment by using nitrogen-doped $\mathrm{TiO}_{2}$ photocatalyst in the degradation and mineralizing a wide class of bacteria using the UV-visible light.

\section{Materials and Methods}

\subsection{Sampling and preparation}

Twenty-eight of water samples were collected (Fig. 1) in strong, brown glass bottles that used after sterilizing and transferred to the lab in ice box during 6 hours. The pH, TDS, and EC were determined in situ by using combined electrode (Hanna Hi93300). In the laboratory, the samples were filtered and analyzed for chemical constituents by using standard procedures (APHA 2012). Sodium $\left(\mathrm{Na}^{+}\right)$and potassium $\left(\mathrm{K}^{+}\right)$were determined by flame photometer (Jenway PFP7), appropriate filters and standard curves. Total Hardness $(\mathrm{TH})$ as $\mathrm{CaCO}_{3}$ and chloride $\left(\mathrm{Cl}^{-}\right)$were analyzed by volumetric methods. Ammonium $\left(\mathrm{NH}_{4}{ }^{+}\right)$, sulfates $\left(\mathrm{SO}_{4}{ }^{2-}\right)$ and nitrates $\left(\mathrm{NO}_{3}{ }^{-}\right)$were estimated by using the calorimetric technique. Calcium $\left(\mathrm{Ca}^{2+}\right)$ and magnesium $\left(\mathrm{Mg}^{2+}\right)$ were determined by using Atomic Absorption Spectrophotometer. Chromium, copper, iron, manganese and zinc were estimated by using Atomic Absorption Spectrometer (Perkin Elmer 400) at the central laboratory of the national research center (NRC), was after filtration and acidification by adding nitric acid to $\mathrm{pH} 2$ (Trick et al., 2008).

The Chemical Oxygen Demand (COD) was determined by $\mathrm{K}_{2} \mathrm{Cr}_{2} \mathrm{O}_{7}$ open reflux method (El Nazer et al., 2017). Four representative samples were selected for treatment technique.

To determine the suitability of water for irrigation, Sodium Absorption ratio (SAR) was applied because it evaluates the sodium hazard in irrigation water (Salman and Elnazer, 2015). SAR is calculated by the following Eq. (1) (Richards, 1954) where, all values in meq/l:

$$
S A R=N a^{+} /\left[\left(\mathrm{Ca}^{2+}+M g^{2+}\right) / 2\right]^{1 / 2}
$$

The water can be classified into four categories based on SAR: excellent (SAR<10), good (10-18), doubtful (18-26) and unsuitable (>26) water for irrigation. 
Drink. Water Eng. Sci. Discuss., https://doi.org/10.5194/dwes-2018-41

Manuscript under review for journal Drink. Water Eng. Sci.

Discussion started: 20 December 2018

(c) Author(s) 2018. CC BY 4.0 License.

(c) (i)

\subsection{Microbial Analysis}

The total bacterial count (TBC) and total count for different bacterial indicator include total coliform, fecal coliform and fecal streptococci were carried out using the most probable number (MPN) technique (APHA, 2012; Divya and Solomon, 2016; Rawway, 2016).

\subsection{Treatment}

\subsubsection{Preparation of nitrogen doped Titania}

Nitrogen-doped $\mathrm{TiO}_{2}$ photocatalyst was prepared through the sol-gel hydrothermal method using titanium n-Butoxide (TNBT) precursor and urea. In this method, TNBT solution and urea was taken in the mole ratio 1:5. The urea solution was added drop wise to a mixture of titanium $\mathrm{n}$. - butoxide and ethanol after stirring for $\sim 24$ hours at room temperature. It was dried at $60^{\circ} \mathrm{C}$ and then calcined at $400{ }^{\circ} \mathrm{C}$ for 4 hours (Cong et al., 2007).

\subsubsection{Photocatalytic reactions}

The Photocatalytic chemical experiments were carried out by using a PHOCAT $120 \mathrm{~W}$ photoreactor. Aqueous dispersion of polluted water containing $\left(1 \mathrm{~g} / 1 \mathrm{TiO}_{2}\right)$ was sonicated for 5 minutes. The polluted water contacting $\mathrm{TiO}_{2}$ was then irradiated using simple photoreactor using ten visible light lamps $\left(\lambda_{\max } 400-700 \mathrm{~nm}\right)$ with a total power of 80 Watt. At intervals of times, $3 \mathrm{ml}$ aliquots of reaction mixture were withdrawn and analyzed. When $\mathrm{TiO}_{2}$ is exposed to the light, which has the photon energy equal or larger than energy gab $\left(\mathrm{E}_{\mathrm{g}}\right)$ the $\mathrm{e}^{-}$in the valence band (VB) can absorb the photon and jump to the conduction band (CB), generating a positive hole in $\mathrm{VB}\left(\mathrm{h}^{+}{ }_{\mathrm{VB}}\right)$ which are highly oxidizing. $\mathrm{h}^{+}{ }_{\mathrm{vB}}$ can subsequently decompose organic compounds and unwanted bacteria into water and other harmless substance that disperse into the atmosphere (Gole et al., 2004; Pelaez et al., 2012).

\section{Results and Discussion}

\subsection{Major characteristics and quality}

The descriptive statistics of the studied samples are presented in Table 1. It appears from the comparison with WHO (2017) specification for drinking water that more than $90 \%$ of water samples could be used for drinking based on $\mathrm{pH}, \mathrm{Mg}^{2+}$ and $\mathrm{K}^{+}$values. Moreover, $70 \%$ could use for drinking based on TDS, $\mathrm{Cl}^{-}, \mathrm{NH}_{4}{ }^{+}$and $\mathrm{NO}_{3}{ }^{-}$; furthermore, $48 \%$ based on $\mathrm{EC}$, $\mathrm{Ca}^{2+}, \mathrm{Na}^{+}$and $\mathrm{SO}_{4}{ }^{2-}$ values. Ninety-three percent of water samples are very good quality and suitable for irrigation of all soils based on sodium adsorption ratio (SAR). 
Drink. Water Eng. Sci. Discuss., https://doi.org/10.5194/dwes-2018-41

Manuscript under review for journal Drink. Water Eng. Sci.

Discussion started: 20 December 2018

(c) Author(s) 2018. CC BY 4.0 License.

\subsection{Status of some heavy metals in water}

Descriptive statistical results are reported in Table 2, and compared with the world health organization (2017). The measured chromium content in water ranges from BDL to $140 \mu \mathrm{g} / \mathrm{l}$. Most of the analyzed samples (89.3\%) contain Cr level below maximum admissible limit for drinking water (Fig. 2a). The iron values vary from BDL up to $420 \mu \mathrm{g} / \mathrm{l}$. Only two samples are out the acceptable limit (Fig. 2b). All the investigated samples have copper, manganese and zinc within the safe limits set by WHO guidelines. Thus, considered satisfactory for drinking purpose.

\subsection{Bacteriological estimation of water}

The results of total bacterial counts (TBCs) at $37^{\circ} \mathrm{C}$ were shown in Table 3, Figs. 3 and 4, that ranged from $2.89 \times 10^{4}$ to $127 \times 10^{4}$ with average $23.5 \times 10^{4}(\mathrm{CFU} / \mathrm{ml})$. In the present study, all of the samples were very highly contaminated with the total bacterial count in comparison with WHO (2017).

The density of total and fecal coliform is presented in Table 3 and Fig. 5. The highest values of total and fecal coliform were 2400 and 1700 (MPN/100ml), respectively; the average values recorded for total and fecal coliform was 497.4 and 358.3 (MPN/100ml), respectively. On the other hand, there are three samples are free from total and fecal coliform bacteria $(<1.8$ (MPN/100 ml)). This may be due to the role of soil where, bacteria are naturally filtered out by soil and rock (Ikhlil, 2009).

The fecal streptococci in water samples range from less than 1.8 to $790 \mathrm{MPN} / 100 \mathrm{ml}$ with an average 115.9 (MPN/100ml) (Table 3 and Fig. 5). From the bacteriological view, results showed higher counts of total bacterial counts, total coliforms, fecal coliforms and fecal streptococci, indicating the contamination of waterlogging with human and animal fecal material (Pelczar et al., 2007). The main source of fecal microorganisms in water samples are wastewater discharges (WHO, 2008). So, all water samples require effective treatment.

\subsection{Treatment of water}

Bactericidal activities of the polluted samples were evaluated and examined for total bacterial counts (TBCs) (at 37 ${ }^{\circ} \mathrm{C}$ and $22^{\circ} \mathrm{C}$ ) and total coliform. In addition, two samples were examined for their content of chemical oxygen demand (COD).

As shown in Table 4, the viable bacteria were completely killed within $60 \mathrm{~min}$ in the $\mathrm{N}$-doped $\mathrm{TiO}_{2}$ suspension under visible light irradiation. As well as more than $82 \%$ of organic residuals. Doping of nitrogen into nanocrystalline $\mathrm{TiO} 2$ results in an extension of its light absorption into the visible region. The highly enhanced photocatalytic activity of $\mathrm{N}^{-\mathrm{TiO}_{2}}$ may be attributed to its higher specific area, red-shifted optical absorption edge and lower optical bandgap compared to undoped$\mathrm{TiO} 2$. The excellent photoactivity of $\mathrm{N}-\mathrm{TiO}_{2}$ compared with undoped one could be explained by cooperation effect between nitrogen species on increasing the photosensitivity in the visible region. Thus, $\mathrm{N}-\mathrm{TiO}_{2}$ is a cheap but a promising photocatalyst for many catalytic applications. Bandgap calculations of the doped- $\mathrm{TiO}_{2}$ photocatalysts would identify the possible electron and/or energy transfer processes in this system. Previous studies suggested an electron transfer to molecular oxygen producing reactive oxygen species (Gole et al., 2004; Selvam and Swaminathan, 2012; Shi et al., 2014). 
Drink. Water Eng. Sci. Discuss., https://doi.org/10.5194/dwes-2018-41

Manuscript under review for journal Drink. Water Eng. Sci.

Discussion started: 20 December 2018

(c) Author(s) 2018. CC BY 4.0 License.

\section{Conclusions}

As a result of the present study, water is containing acceptable levels of $\mathrm{Cr}, \mathrm{Cu}, \mathrm{Fe}, \mathrm{Mn}$ and $\mathrm{Zn}$ according to WHO specification for drinking water. The results of microbiological aspects indicate that all the studied samples contain a viable count of heterotrophic bacteria, total coliform, fecal coliform and fecal streptococci, reflecting the contamination with human and animal fecal material, as well as high values of COD may be due to leakage from sewage and irrigation wastewater;furthermore, industrial activities in the city. Photocatalytic treatment of polluted water using nano-titania in presence of solar radiation has shown high efficiency towards the removal of about $95 \%$ and $82 \%$ of microbial pollutants and organic residuals.

\section{Recommendations}

The present study suggests the following recommendations be taken into account:

- Stop pumping logged water into the underline Miocene aquifer to prevent contamination of water aquifer.

- To enhance the effect of any solution, the sewage drainage and water supply networks in the city should be improved.

- Create an effective covered drainage system or drip irrigation in Orabi farms as well as green areas in El Obour city.

- Applying the photocatalytic treatment which shows the ability of photocatalytic technique towards the removal of microbial pollutants and organic residuals in safe and inexpensive ways.

\section{References}

Abdel-Hafiz, M.A., Zeid, S.A.M., Seleem, E.M., and Salman, S.A.: Geochemical and microbial evaluation of shallow groundwater and a new approach for water treatment in El Obour City, east Cairo, Egypt, 12th Int. Geological Conference (IGC12) in Jeddah, Saudi Arabia, 2018.

Abdel-Hafiz, M.A.: Hydrochemical and environmental assessment of waterlogging and soil for different purposes at El Obour City, East Cairo, Egypt, MSc Thesis, Fac Sci, Al-Azhar Univ, Assiut, 273, 2017.

Abou Heleika, M.M. and Atwia, M.G.: Integrated electrical resistivity and hydrogeological studies for delineating the Miocene aquifer at Eastern side of Nile Delta, Egypt, Arab. J. Geosci., 8, 4657-4667, 2015.

Adam Sigler, W. and Bauder, J.: Total Coliform and E. coli Bacteria, Montana State Univ. Extension Water Quality Program Dep. Land Resour. Environ. Sci., 2011.

AlShahat, F.M., Sadek, M.A., Mostafa, W.M., and Hagagg, K.: Hydrogeochemical Indicators for Radioactive Waste Disposal Site Survey to the East of Nile Delta, Egypt, Int. J. Curr. Eng. Technol., 4(2), 549-556, 2014.

APHA (American public health association): Standard methods for the examination of water and wastewater, 22nd edn., by AWWA, WEF (Water Environment Federation), 1496, 2012.

Batzill, M., Morales, E.H., and Diebold, U.: Influence of nitrogen doping on the defect formation and surface properties of $\mathrm{TiO}_{2}$ Rutile and Anatase. Physical Review Letters, vol. 96, no. 2, pp. 1-4, 2006.

Bradl, H.: Heavy Metals in the Environment: Origin, Interaction and Remediation, London: Acad. Press., 2002. 
Drink. Water Eng. Sci. Discuss., https://doi.org/10.5194/dwes-2018-41

Manuscript under review for journal Drink. Water Eng. Sci.

Discussion started: 20 December 2018

(c) Author(s) 2018. CC BY 4.0 License.

Cong, Y., Zhang, J.L., Chen, F., and Anpo, M.: Synthesis and characterization of nitrogen-doped $\mathrm{TiO}_{2}$ nanophotocatalyst with high visible light activity, J. Phys. Chem. C, 111(19), 6976-6982, 2007.

Crider, Y., Sultana, S., Unicom, L. et al.: Can you taste it? Taste detection and acceptability thresholds for chlorine residual in drinking water in Dhaka, Bangladesh, Sci. Total Environ., 613-614, 840-846, 2018.

Deborde, M. and Gunten, U.: Reactions of chlorine with inorganic and organic compounds during water treatment—Kinetics and mechanisms: A critical review, Water Res., 42, 13-51, 2008.

Divya, A.H. and Solomon, P.A.: Effects of some water quality parameters especially total coliform and fecal coliform in surface water of Chalakudy river, Proc. Tech., 24, 631 - 638, 2016.

El Nazer, H.A., Salman, S.A., and Elnazer, A.A.: Irrigation water quality assessment and a new approach to its treatment using photocatalytic technique: Case study Yaakob village, SW Sohag, Egypt, J. Mater. Environ. Sci., 8(1), 310-317, 2017.

El Nazer, H.A., Zeid, S.A.M., Seleem, E.M., Salman, S.A., and Abdel-Hafiz, M.A.: Geochemical and microbial evaluation of shallow groundwater and a new approach for water treatment in El Obour City, Egypt, $55^{\text {th }}$ Annual Scientific Meeting at the Egyptian Mineral Resour. Authority, GSE, DOI:10.13140/RG.2.2.25192.57609, 2017.

Fuldner, S., Mild, R., Siegmund, H.I. et al.: Green-light photocatalytic reduction using dye-sensitized TiO2 and transition metal nanoparticles, Green Chem., 12, 400-406, 2010.

Fuldner, S., Mitkina, T., Trottmann, T. et al.: Urea derivatives enhance the photocatalytic activity of dye-modified titanium dioxide, Photochem. Photobio. Sci., 10, 623-625, 2011.

Gagnon, J., Clift, M.J.D., Vanhecke, D. et al.: Synthesis, characterization, antibacterial activity and cytotoxicity of hollow $\mathrm{TiO} 2$-coated $\mathrm{CeO} 2$ nanocontainers encapsulating silver nanoparticles for controlled silver release, J. Mater. Chem. B, 4(6), 1166-1174, 2016.

Gole, J., Stout, J., Burda, C., Lou, Y., and Chen, X.: Highly efficient formation of visible light tunable $\mathrm{TiO}_{2}-\mathrm{xN}_{\mathrm{x}}$ photocatalysts and their transformation at the nanoscale, J. Phys. Chem. B, 108, 1230-1240, 2004.

Gray, N.F.: Pathogen Control in Drinking Water, in: Microbiology of Waterborne Diseases, 2nd edn., edited by: Percival, S.L., Yates, M.V., Williams, D.W., Chalmers, R.L.M., and Gray, N.F., Elsevier Ltd., 537-569, 2014.

Hrudey, S.E.: Chlorination disinfection by-products, public health risk tradeoffs and me, Water Res., 43(8), 2057-2092, 2009.

Ikhlil, A.I.H.: Groundwater Quality of Springs and Dug Wells in Dura Area, M.Sc. Thesis, College of Graduate Studies and Academic Res., Hebron Univ., Palestine, 2009.

Kamel, M.S.: Bacterial Assessment of Surface Resources of Drinking Water at Assiut Governorate, MSc Thesis, Botany Micro Dep., Fac. Sci., Al-Azhar Univ., Assiut, 136, 2016.

Kotloff, K., Nataro, J., Blackwelder, W., and Al, E.: Burden and aetiology of diarrhoeal disease in infants and young children in developing countries (the Global Enteric Multicenter Study, GEMS): a prospective, case-control study, The Lancet, 382, 209-222, 2013.

Krasner, S.W., Weinberg, H.S., Richardson, S.D. et al.: Occurrence of a new generation of disinfection byproducts, Environ. Sci. Technol., 40, 7175-7185, 2006.

Linsebigler, L., Lu, G., and Yates, Y.T.: Photocatalysis on TiO2 Surfaces: Principles, Mechanisms, and Selected Results, Chem. Rev., 95, 735-758, 1995.

Liu, J., Platts-Mills, J.A., Juma, J. et al.: Use of quantitative molecular diagnostic methods to identify causes of diarrhoea in children: a reanalysis of the GEMS case-control study, The Lancet, 388, 1291-1301, 2016.

Murray, C.J.L., Vos, T., Lozano, R. et al.: Disability-adjusted life years (DALYs) for 291 diseases and injuries in 21 regions, 1990- 2010: a systematic analysis for the Global Burden of Disease Study 2010, The Lancet, 380(9859), 2197-2223, 2012. 
Drink. Water Eng. Sci. Discuss., https://doi.org/10.5194/dwes-2018-41

Manuscript under review for journal Drink. Water Eng. Sci.

Discussion started: 20 December 2018

(c) Author(s) 2018. CC BY 4.0 License.

NRC (National Research Council): Drinking Water and Health, National Academy of Sciences, Washington, D.C., 938, 1977.

PCRWR (Pakistan Council for Research in Water Resources): National water quality monitoring program, Water Quality Report, Islamabad, Pakistan: PCRWR. Available at http://www.pcrwr.gov.pk/wq_phase3_report/ TOC. Htm, 2005.

Pelaez, M., Nolan, N., Pillai, S., Seery, M., and Falaras, P.: A Review on the Visible Light Active Titanium Dioxide Photocatalysts for Environmental Applications, Appl. Catal. B: Environ., 125, 331-349. doi:10.1016/j.apcatb.2012.05.036, 2012.

Pelczar, M.J., Chan, E.C.S., and Krieg, N.R.: Microbiology, 5th edn. Tata McGraw Hill Co, New Delhi, 2007.

Plewa, M.J., Wagner, E.D., Richardson, S.D. et al.: Chemical and biological character- ization of newly discovered iodoacid drinking water disinfec- tion byproducts, Environ. Sci. Technol., 38, 4713-4722, 2004.

Ramadan, M.A.: Bacterial assessment of groundwater resources at Assiut Governorate, MSc Thesis, Fac. Sci., Al-Azhar Univ., Assiut, 202, 2016.

Rawway, M., Kamel, M.S., and Abdul-Raouf, U.M.: Microbial and Physico-Chemical Assessment of Water Quality of the River Nile at Assiut Governorate (Upper Egypt), J. Ecol. Health Environ., 4(1), 7-14, 2016.

Richards, L.A.: Diagnosis and improvement of saline and alkali soils, US Dept Agri., Handb. 60, USDA, Washington, DC, 1954.

Richardson, S.D., Thruston, A.D., Rav-Acha, C. et al.: Tribromopyrrole, brominated acids and other disinfection byproducts produced by disinfection of drinking water rich in bromide, Environ. Sci. Technol., 37(17), 3782-3793, 2003.

Richardson, S.D.: New disinfection by-product issues: emerging DBPs and alternative routes of exposure, Global Nest J., 7(1), 43-60, 2005.

Salman, S.A. and Elnazer, A.A.: Evaluation of groundwater quality and its suitability for drinking and agricultural uses in SW Qena Governorate, Egypt, Adv. Nat. Appl. Sci., 9(5), 16-26, 2015.

Seleem, E.M., Zeid, S.A.M., Salman, S.A., and Abdel-Hafiz, M.A.: Determination of Water Quality Index (WQI) for water logging and its suitability for drinking and agricultural usages in El Obour city, east Cairo, Egypt, 53th Annual Scientific Meeting, GSE, Egypt, doi:10.13140/RG.2.2.32926.33602, 2015.

Selvam, K. and Swaminathan, M.: Nano $\mathrm{N}^{-\mathrm{TiO}_{2}}$ mediated selective photocatalytic synthesis of quinaldines from Nitrobenzenes, RSC Advances, 2, 2848-2855, 2012.

Shar, A.H., Kazi, Y.F., Zardari, M., and Soomro, I.H.: Enumeration of total and fecal coliform bacteria in drinking water of Khairpur City Sindh Pakistan, Pak. J. Med. Res., 47, 18-21, 2008.

Shi, J., Ai, H., Chen, J. et al., Nitrogen doped titania plates with dominant $\left\{\begin{array}{lll}0 & 0 & 1\end{array}\right\}$ facets: Microstructure and property evolution, and their photocatalytic activities, J. Mol. Catal. A-Chem., 395, 420-427. doi:10.1016/j.molcata.2014.09.007, 2014.

Trick, J.K., Stuart, M., and Reeder, S.: Contaminated Groundwater Sampling and Quality Control of Water Analyses, in: Environmental geochemistry site characterization, data analysis and case histories, edited by: Vivo, D.E., Belkin, H.E., and Lima, A., Elsevier, London, UK, 29-57, 2008.

WHO (World Health Organization): Guidelines for Drinking-Water Quality. 2nd edn., Health Criteria and Other Supporting Information, WHO, Geneva, Switzerland, 2, 973,1996.

WHO: Environmental Health Criteria 216 - Disinfectant and Disinfectant By-products, 2000.

WHO: Trihalomethanes in Drinking-water: Background Document for Development of WHO Guidelines for Drinking-water Quality, 2005.

WHO: Guidelines for drinking water quality, Incorporating 1 and 2nd addenda, Recommendations, 3rd edn., WHO, Geneva, $515,2008$. 
Drink. Water Eng. Sci. Discuss., https://doi.org/10.5194/dwes-2018-41

Manuscript under review for journal Drink. Water Eng. Sci.

Discussion started: 20 December 2018

(c) Author(s) 2018. CC BY 4.0 License.

(c) (1)

WHO: Guidelines for drinking-water quality: 4th Geneva, 541, 2017.

Zeid, S.A.M., Seleem, E.M., Salman, S.A., and Abdel-Hafiz, M.A.: Water quality index of shallow groundwater and assessment for different usages in El-Obour city, Egypt, J. Mater. Environ. Sci., 9(7), 1957-1968, 2018.

Zeid, S.A.M., Seleem, E.M., Salman, S.A., and Abdel-Hafiz, M.A.: Estimation pollution sources using statistical analysis in El Obour city, Egypt, 3rd ICNHBAS, 5-7 August, Hurghada, Egypt, 2017.

Zeid, S.A.M., Seleem, E.M., Salman, S.A., Elnazer, H.A., and Abdel-Hafiz, M.A.: Evaluation and treatment of waterlogging for drinking, irrigation and industrial uses in El Obour city East Cairo, Egypt, $2^{\text {ed }}$ ICNHBAS, Hurghada, Egypt, 1-6 August, doi: 10.13140/RG.2.1.1081.8964, 2015.

Zhang, Q., Gaafar, M., Yang R. et al.: Field data analysis of active chlorine-containing stormwater samples, J. Environ. Manag., 206, 51-59, 2018. 
Drink. Water Eng. Sci. Discuss., https://doi.org/10.5194/dwes-2018-41

Manuscript under review for journal Drink. Water Eng. Sci.

Discussion started: 20 December 2018

(c) Author(s) 2018. CC BY 4.0 License.

Table 1: Descriptive statistics of the physicochemical parameters, SAR and RSC of water compared with WHO (2017) specification.

\begin{tabular}{|c|c|c|c|c|c|c|c|c|c|c|c|c|c|}
\hline & pH & $\begin{array}{l}\text { TDS } \\
\mathrm{mg} / \mathrm{l}\end{array}$ & $\begin{array}{c}\mathbf{E C} \\
\mu \mathrm{S} / \mathrm{cm}\end{array}$ & $\begin{array}{c}\mathbf{T H} \\
\mathrm{mg} / \mathrm{l}\end{array}$ & $\begin{array}{l}\mathrm{Ca}^{2+} \\
\mathrm{mg} / \mathrm{l}\end{array}$ & $\begin{array}{l}\mathbf{M g}^{2+} \\
\mathrm{mg} / \mathrm{l}\end{array}$ & $\begin{array}{l}\mathbf{N a}^{+} \\
\mathrm{mg} / \mathrm{l}\end{array}$ & $\begin{array}{c}\mathbf{K}^{+} \\
\mathrm{mg} / \mathrm{l}\end{array}$ & $\begin{array}{c}\mathbf{S O}_{4}{ }^{2-} \\
\mathrm{mg} / \mathrm{l}\end{array}$ & $\begin{array}{c}\mathrm{Cl}^{-} \\
\mathrm{mg} / \mathrm{l}\end{array}$ & $\mathrm{NO}_{3}^{-}$ & $\mathrm{NH}_{4}{ }^{+}$ & SAR \\
\hline Mean & 7.69 & 1136.1 & 2241.6 & 314.4 & 85.3 & 33.9 & 371.8 & 5.9 & 466.5 & 273.2 & 40.0 & 0.30 & 7.88 \\
\hline Median & 7.57 & 796.6 & 1536.1 & 254.1 & 69.7 & 22.5 & 247.5 & 6.0 & 223.5 & 130.6 & 16.0 & 0.16 & 6.16 \\
\hline SD & 0.54 & 983.0 & 1966.2 & 222.9 & 51.9 & 32.8 & 409.4 & 3.4 & 588.6 & 379.3 & 75.5 & 0.67 & 6.79 \\
\hline Range & 3.05 & 3568.6 & 7549.5 & 958.6 & 230.0 & 135 & 1260 & 12.3 & 2658 & 1428 & 346.5 & 3.65 & 23.2 \\
\hline Min. & 7.18 & 318.6 & 660.9 & 85.1 & 15.0 & 5.0 & 30.0 & 0.5 & 42.0 & 31.8 & 0.0 & 0.06 & 0.74 \\
\hline Max. & 8.2 & 3887.2 & 8210.4 & 1043.7 & 245.0 & 140 & 1290 & 12.9 & 2700 & 1460 & 346.5 & 3.71 & 23.9 \\
\hline Q1 & 7.49 & 420.6 & 818.8 & 169.5 & 50.0 & 15.0 & 73.9 & 3.1 & 83.8 & 60.0 & 3.2 & 0.15 & 2.15 \\
\hline Q3 & 7.77 & 1236.3 & 2350.0 & 365.3 & 100.0 & 41.3 & 453.8 & 8.7 & 723.8 & 248.3 & 28.2 & 0.21 & 12.9 \\
\hline $\begin{array}{l}\text { WHO } \\
(2017)\end{array}$ & $\begin{array}{c}6.5- \\
8.5\end{array}$ & 1000 & 1500 & 500 & 75 & 100 & 200 & 12 & 250 & 250 & 50 & 0.2 & -- \\
\hline
\end{tabular}

SD: Standard Deviation

Min. Minimum

Max. Maximum

Q1: $1^{\text {st }}$ quartile

Q3: $3^{\text {rd }}$ quartile 
Drink. Water Eng. Sci. Discuss., https://doi.org/10.5194/dwes-2018-41

Manuscript under review for journal Drink. Water Eng. Sci.

Discussion started: 20 December 2018

(c) Author(s) 2018. CC BY 4.0 License.

Table 2: Summary statistics of some heavy metals and compared with WHO (2017) specification.

\begin{tabular}{cccccc}
\hline & $\mathbf{C r}$ & $\mathbf{C u}$ & $\mathbf{F e}$ & $\mathbf{M n}$ & $\mathbf{Z n}$ \\
& $\mu \mathrm{g} / 1$ & $\mu \mathrm{g} / \mathrm{l}$ & $\mu \mathrm{g} / \mathrm{l}$ & $\mu \mathrm{g} / \mathrm{l}$ & $\mu \mathrm{g} / \mathrm{l}$ \\
\hline Mean & 23.89 & 20.71 & 73.93 & 92.86 & 78.57 \\
\hline Median & 13.5 & 0.0 & 35 & 100 & 40 \\
\hline SD & 31.84 & 67.87 & 98.67 & 101.57 & 196.92 \\
\hline Range & 140 & 350 & 420 & 400 & 1070 \\
\hline Min. & BDL & BDL & BDL & BDL & 10 \\
\hline Max. & 140 & 350 & 420 & 400 & 1080 \\
\hline Q1 & 8 & BDL & 20 & BDL & 30 \\
\hline Q3 & 22.75 & BDL & 82.5 & 200 & 60 \\
\hline WHO (2017) & $\mathbf{5 0}$ & $\mathbf{2 0 0 0}$ & $\mathbf{3 0 0}$ & $\mathbf{4 0 0}$ & $\mathbf{3 0 0 0}$ \\
\hline BDL: blow & & & & & \\
\hline
\end{tabular}

BDL: below detection limit 
Drink. Water Eng. Sci. Discuss., https://doi.org/10.5194/dwes-2018-41

Manuscript under review for journal Drink. Water Eng. Sci.

Discussion started: 20 December 2018

(c) Author(s) 2018. CC BY 4.0 License.

Table 3: The total bacterial count and bacterial indicators of water samples at El Obour area.

\begin{tabular}{|c|c|c|c|c|}
\hline \multirow{2}{*}{$\begin{array}{l}\text { Samples } \\
\text { Number }\end{array}$} & \multirow{2}{*}{$\begin{array}{c}\text { Total bacterial count } \times 10^{4} \\
(\mathrm{CFU} / \mathrm{ml})\end{array}$} & \multicolumn{3}{|c|}{$\begin{array}{l}\text { Bacterial indicators } \\
\text { (MPN-index /100ml) }\end{array}$} \\
\hline & & TC & FC & FS \\
\hline 1 & 4.4 & $<<1.8$ & $<1.8$ & $<1.8$ \\
\hline 2 & 7.3 & 1200 & 1100 & 460 \\
\hline 3 & 3.4 & 580 & 270 & 220 \\
\hline 4 & 4.8 & 580 & 480 & 260 \\
\hline 5 & 69 & 1.8 & 1.8 & $<1.8$ \\
\hline 6 & 47 & 260 & 250 & 3.7 \\
\hline 7 & 11 & 270 & 250 & 3.6 \\
\hline 8 & 50 & 320 & 310 & 61 \\
\hline 9 & 6.0 & 310 & 260 & 1.8 \\
\hline 10 & 32 & 380 & 310 & 1.8 \\
\hline 11 & 7.0 & 260 & 220 & $<1.8$ \\
\hline 12 & 127 & 460 & 260 & 9.1 \\
\hline 13 & 78 & 460 & 410 & 260 \\
\hline 14 & 11 & $<1.8$ & $<1.8$ & $<1.8$ \\
\hline 15 & 11.1 & 430 & 400 & 250 \\
\hline 16 & 4.8 & 3.7 & 3.6 & 1.8 \\
\hline 17 & 20 & $<1.8$ & $<1.8$ & $<1.8$ \\
\hline 18 & 8.7 & 940 & 840 & 790 \\
\hline 19 & 25 & 1700 & 1200 & 250 \\
\hline 20 & 2.98 & 270 & 220 & 120 \\
\hline 21 & 17.8 & 460 & 260 & 250 \\
\hline 22 & 3.1 & 2400 & 1700 & 260 \\
\hline 23 & 9.7 & 2100 & 840 & 3.6 \\
\hline 24 & 7.0 & 3.6 & 1.8 & 1.8 \\
\hline 25 & 43 & 260 & 220 & 18 \\
\hline 26 & 41 & 270 & 220 & 18 \\
\hline 27 & 3.0 & 3.7 & 3.6 & 1.8 \\
\hline 28 & 3.3 & 3.7 & 1.8 & $<1.8$ \\
\hline Max & 127 & 2400 & 1700 & 790 \\
\hline Min & 2.98 & $<1.8$ & $<1.8$ & $<1.8$ \\
\hline Average & 23.51 & 497.4 & 358.3 & 115.9 \\
\hline
\end{tabular}


Drink. Water Eng. Sci. Discuss., https://doi.org/10.5194/dwes-2018-41

Manuscript under review for journal Drink. Water Eng. Sci.

Discussion started: 20 December 2018

(c) Author(s) 2018. CC BY 4.0 License.

Table 4: Bacterial load and COD values before and after treatment.

\begin{tabular}{|c|c|c|c|c|}
\hline \multicolumn{5}{|c|}{ Before Treated } \\
\hline \multirow{2}{*}{$\begin{array}{c}\text { Sample } \\
\text { No. }\end{array}$} & \multicolumn{2}{|c|}{$\begin{array}{c}\text { Total Bacterial counts } \times \mathbf{1 0}^{\mathbf{3}} \\
\mathrm{CFU} / \mathrm{ml}\end{array}$} & \multirow{2}{*}{$\begin{array}{c}\text { Total coliform } \\
\text { MPN-index / 100ml }\end{array}$} & \multirow{2}{*}{$\begin{array}{c}\text { COD } \\
\left(\mathrm{mg} \mathrm{O}_{2} / \mathrm{l}\right)\end{array}$} \\
\hline & at $37^{\circ} \mathrm{C}$ & at $22{ }^{\circ} \mathrm{C}$ & & \\
\hline 3 & 6.0 & 5.3 & 900 & 230.4 \\
\hline 11 & 48 & 22 & 1500 & 960.8 \\
\hline 19 & 12 & 8 & 150 & \\
\hline 23 & 90 & 64 & 750 & \\
\hline
\end{tabular}

After Treated

\begin{tabular}{|c|c|c|c|c|}
\hline \multirow[t]{2}{*}{$\begin{array}{c}\text { Sample } \\
\text { No. }\end{array}$} & \multicolumn{2}{|c|}{$\begin{array}{c}\text { Total Bacterial counts } \\
\text { CFU/ml }\end{array}$} & \multirow[t]{2}{*}{$\begin{array}{c}\text { Total coliform } \\
\text { MPN-index / 100ml }\end{array}$} & \multirow[t]{2}{*}{$\begin{array}{c}\text { COD } \\
\left(\mathrm{mg} \mathrm{O}_{2} / 1\right)\end{array}$} \\
\hline & at $37^{\circ} \mathrm{C}$ & at $22^{\circ} \mathrm{C}$ & & \\
\hline 3 & 2 & 15 & $<1.8$ & 30 \\
\hline 11 & 2 & $<1.8$ & $<1.8$ & 164 \\
\hline 19 & 4 & $<1.8$ & $<1.8$ & \\
\hline 23 & 7 & 2 & $<1.8$ & \\
\hline
\end{tabular}


Drink. Water Eng. Sci. Discuss., https://doi.org/10.5194/dwes-2018-41

Manuscript under review for journal Drink. Water Eng. Sci.

Discussion started: 20 December 2018

(C) Author(s) 2018. CC BY 4.0 License.

(c) (1)
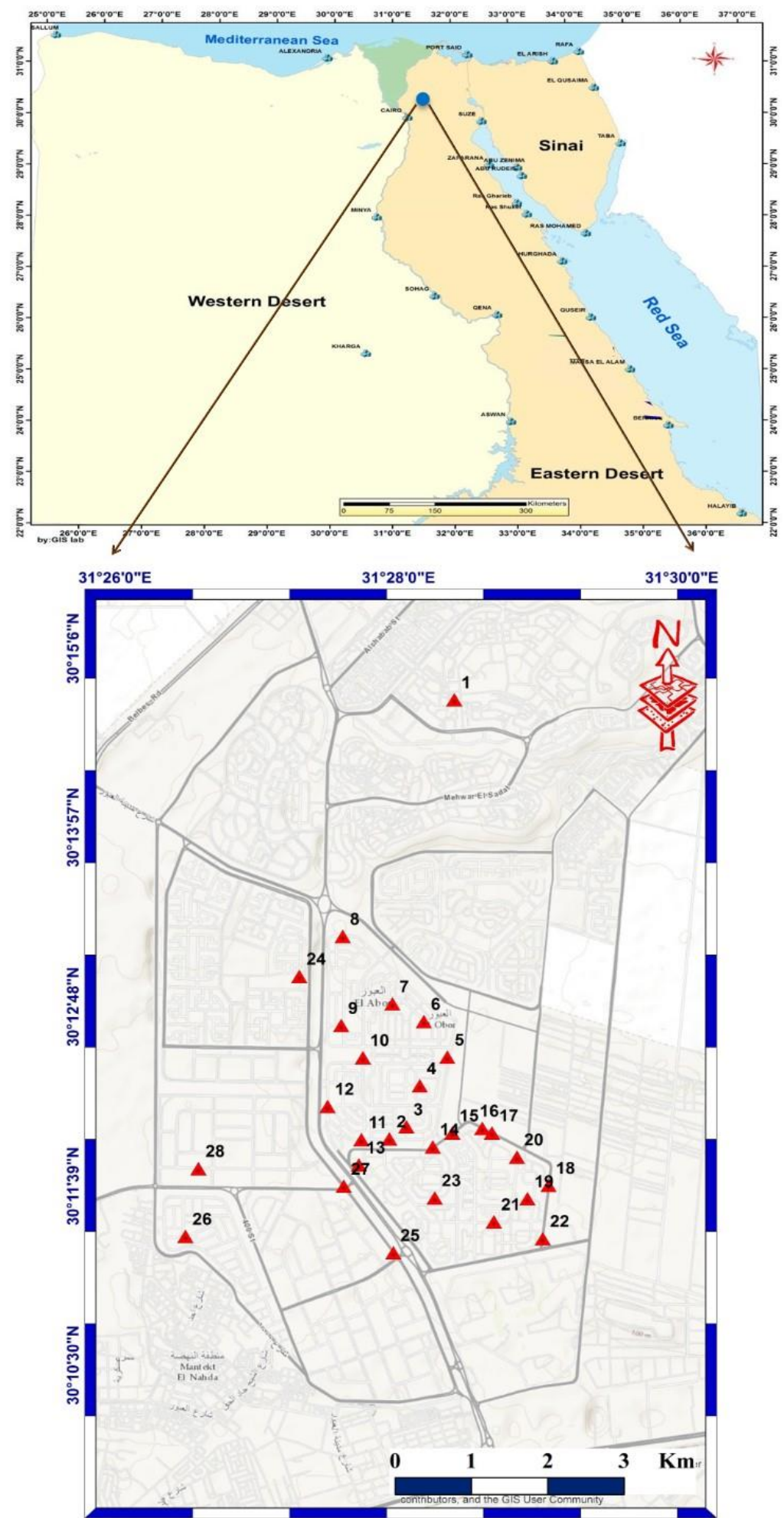

Figure 1: Location map of the collected water samples in the study area. 
Drink. Water Eng. Sci. Discuss., https://doi.org/10.5194/dwes-2018-41

Manuscript under review for journal Drink. Water Eng. Sci.

Discussion started: 20 December 2018

(c) Author(s) 2018. CC BY 4.0 License.

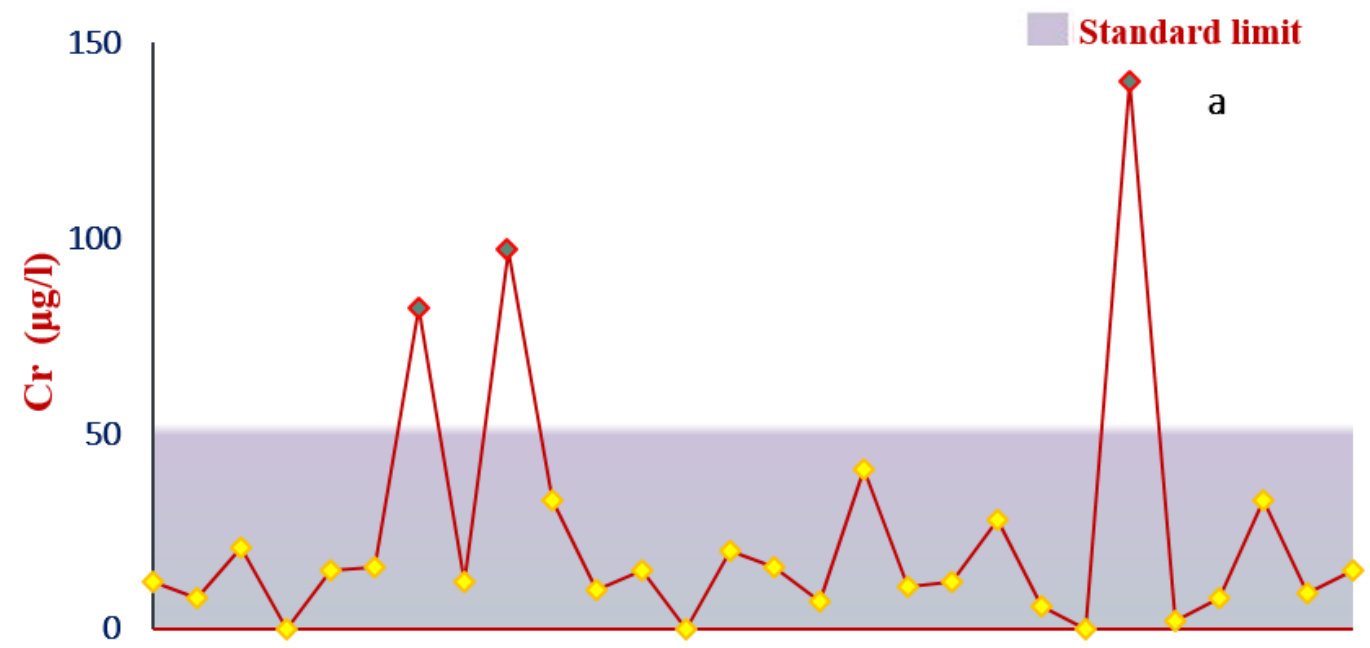

$122 \quad 3 \quad 4 \quad 5 \quad 6 \quad 7 \quad 8 \quad 910111213141516171819202122232425262728$

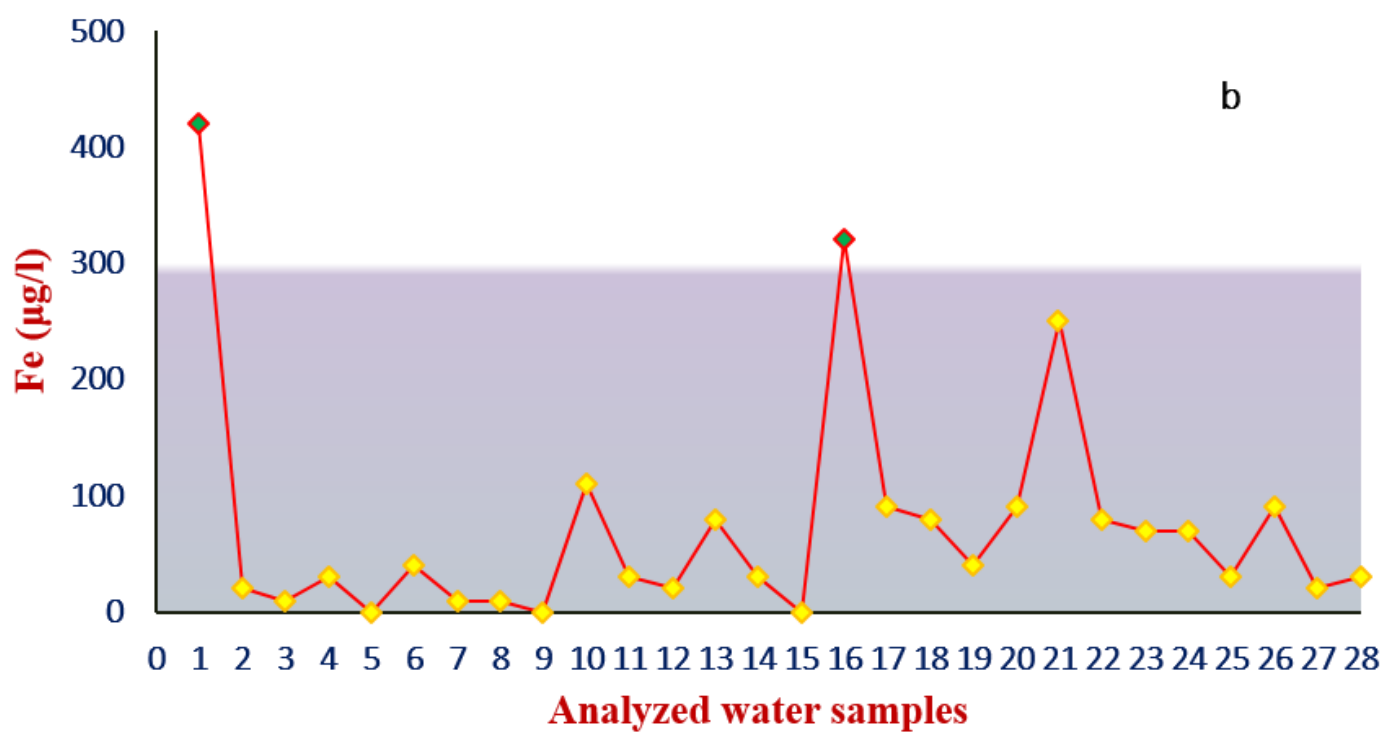

Figure 2: Comparison between WHO standard and both [(a) $\mathrm{Cr}$ and (b) Fe] values. 
Drink. Water Eng. Sci. Discuss., https://doi.org/10.5194/dwes-2018-41

Manuscript under review for journal Drink. Water Eng. Sci.

Discussion started: 20 December 2018

(c) Author(s) 2018. CC BY 4.0 License.

Figure 3: Total bacterial counts in water samples at the study area.

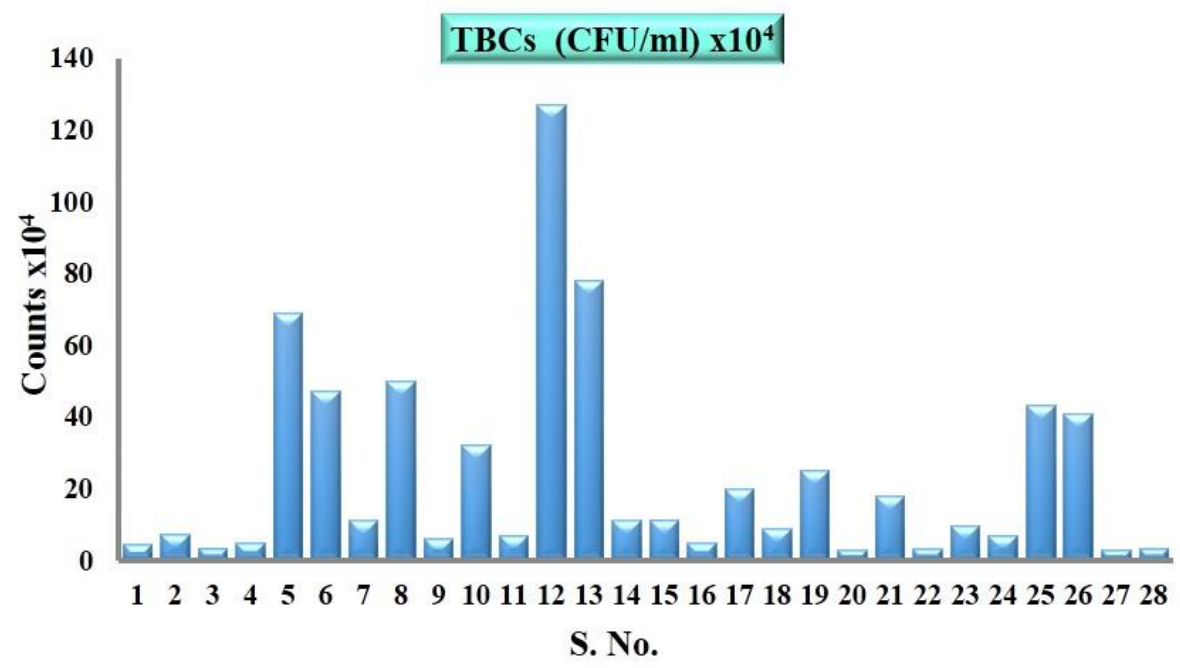

Figure 3: Total bacterial counts in water samples at the study area. 
Drink. Water Eng. Sci. Discuss., https://doi.org/10.5194/dwes-2018-41

Manuscript under review for journal Drink. Water Eng. Sci.

Discussion started: 20 December 2018

(c) Author(s) 2018. CC BY 4.0 License.

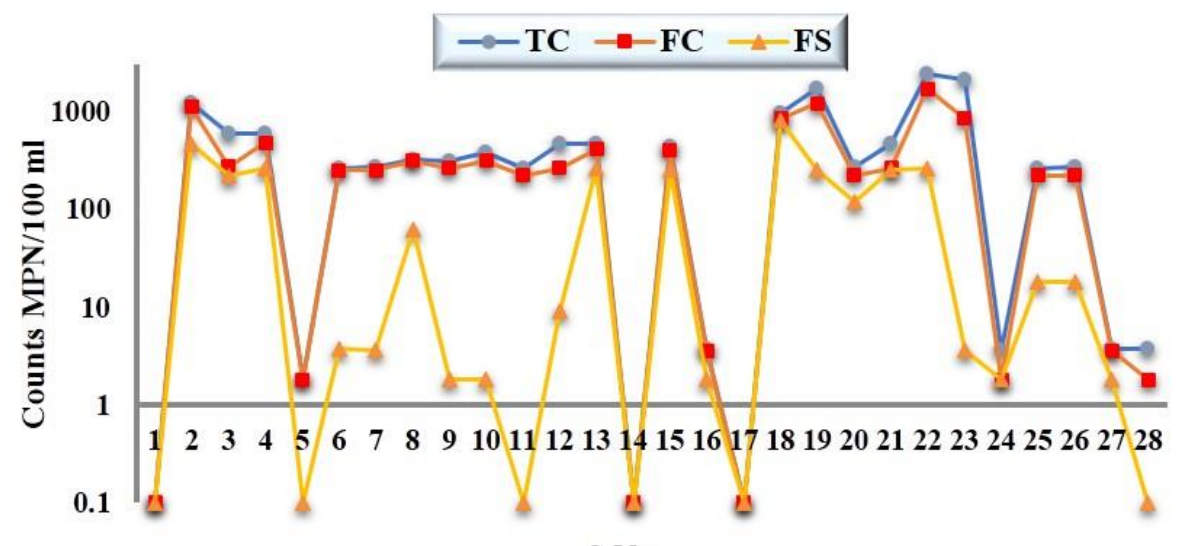

S.No.

Figure 4: Bacterial indicators in water samples. 